$B$

J. bio-sci. 19: 7-14, 2011

ISSN 1023-8654

http://www.banglajol.info/index.php/JBS/index

\title{
OPTIMIZATION OF ALKALI-THERMOSTABLE AND CELLULASE-FREE XYLANASE PRODUCTION FROM BACILLUS SP.
}

\author{
S C D Sharma, M S Shovon, A K M Asaduzzaman, M G Sarowar Jahan, T Yeasmin, N Roy* \\ Department of Biochemistry and Molecular Biology, University of Rajshahi, Rajshahi 6205, Bangladesh
}

\begin{abstract}
Context: To analyze the nutritional and physicochemical parameters for the production of alkali-thermostable and cellulase free xylanase from bacteria.

Objectives: The aim of this study was to isolation and identification and of alkali-thermostable and cellulase free xylanase producing bacteria from soil as well as optimization of process parameters for xylanase production.

Materials and Methods: The bacterium Bacillus $\mathrm{sp}$. was isolated from soil by serial dilution technique on xylan agar medium and identified by morphological and biochemical studies. The production of xylanase was carried out on xylan broth medium and xylanase activity was assayed by dinitrosalicylic acid (DNS) method. The effect of cultural parameters on the production of xylanase was determined by measuring the activity of xylanase. The effect of temperature and pH on the activity of partially purified xylanase as well as substrate specificity of xylanase were examined.
\end{abstract}

Results: The maximum xylanase production ( $4000 \mathrm{U} / \mathrm{L}$ ) by a Bacillus $\mathrm{sp}$. was attained when the medium containing $0.5 \%$ wheat bran xylan and peptone at $\mathrm{pH} 8.0$ and $50-55^{\circ} \mathrm{C}$ within $48-60 \mathrm{~h}$. The partially purified xylanase was optimally active at $\mathrm{pH} 9.0$ and $55^{\circ} \mathrm{C}$. The xylanase showed high substrate activity towards wheat bran xylan but no activity towards cellulose, carboxymethyl cellulose and starch. Thus the enzyme was alkali-thermostable and cellulase free xylanase.

Conclusion: The results obtained in this study suggest that the Bacillus $\mathrm{sp}$. used is highly potential and useful for the production of cellulase free xylanase.

Key words: Alkali-thermostable, cellulase-free xylanase, optimization, Bacillus sp.

\section{Introduction}

Xylanase, an extracellular enzyme, is the key enzyme for the breakdown of xylan. Xylan, the major hemicellulose component in plant cell walls, is a polysaccharide composed of $\beta$-1, 4-linked xylo-pyranose units (Saha 2003). Xylanase degrades xylan to short chain xylooligo-saccharides of varying lengths (Krengel et al.1996). To date xylanases have increased their importance due to their potential applications in industrial processes such as in biomass fuel, bio bleaching, wine industry, improving animal feed and production of ethanol (Tucker et al. 1989, Xu et al. 2000, Nunez et al. 2001, Sudha et al. 2003, Moers et al. 2003), modification of cereal-based food stuffs (Tuohy et al. 1989), improving the digestibility of animal feed stocks (Yin et al. 2001), bioconversion of lingo cellulosic material and agro-wastes to fermentable products (Prema 2005) and pre-bleaching of paper pulps (Gubitz et al. 1997, Viikkari et al. 1986). These uses have increased a great demand for xylanase production (Bocchini et al. 2003). Haltrich et al (1996) gave an overview of fungal xylanase and showed that the enzyme can be produced by a number of microorganisms including bacteria, yeast and filamentous fungi.

Chlorinated organic compounds produced from chemical bleaching technologies are harmful to the environment and need to be substituted by eco-friendly procedures. Xylanases cleave and solubilize reprecipitated xylan and lignin located on the surface of the micro fibrils. This facilitates pulp bleaching and lowers chlorine consumption thereby reducing the discharge of toxic-organochlorine compounds in the environment (Senior et al. 1992, Tolan and Canovas 1992). Pre-bleaching of paper pulp also requires the

"Corresponding author Email: subeddev@yahoo.com 
use of cellulase free xylanases, since cellulases may adversely affect the quality of the paper pulp by destroying the structure of cellulose and thus diminish the quality of the pulp (Techapun et al. 2003). For the development of suitable xylanase as a pre-bleaching agent, the stability of enzyme at higher optimum pH and temperature is desirable (Beg et al. 2000). The major current application of xylanases is in the pulp and paper industries where the high temperature and alkaline $\mathrm{pH}$ of the pulp substrate requires thermoalkaliphilic enzymes for efficient biobleaching (Kulkarni et al. 1999). A thermostable xylanase would also be beneficial in animal's feeds if added to the feeds before the pelleting process. To search commercial feasibility, enzyme production must be increased by introducing a more potent strain and by optimizing nutritional and cultural conditions such as carbon and nitrogen sources, time course, incubation period and initial $\mathrm{pH}$. So the main aim of the present investigation reported here was to optimize the production of an alkali-thermostable and cellulase free endo-xylanase by an extreme thermophile Bacillus $\mathrm{sp}$.

\section{Materials and Methods}

Isolation and identification of Bacillus sp.: For the isolation of the bacterium Bacillus sp. the waste soil samples were collected using pre-sterilized sample bottles and sterile spatula from different areas of sugarcane industry. The soil samples were diluted by serial dilution and cultured on xylan agar media. The isolate producing clear transparent zone around the colony on xylan agar plate was selected as xylanolytic bacteria and purified by sub cultured. The identification of Bacillus sp. was confirmed on the basis of morphological and biochemical characteristics using the criteria of Bergey's Manual of Systematic Bacteriology (Holt et al. 1993). The culture was maintained on wheat bran xylan agar slants by weekly transfers onto fresh slants and was stored at $4^{\circ} \mathrm{C}$ in refrigerator.

Xylanase production and assay: The production of xylanase was carried out using Bacillus sp. cultured in $250 \mathrm{ml}$ Erlenmeyer flasks containing $100 \mathrm{ml}$ of medium [0.5\% wheat bran xylan, $0.5 \%$ yeast extract, $1 \%$ peptone, $0.5 \% \mathrm{NaCl}$ ] at $50^{\circ} \mathrm{C}$ for 2 days in an incubator on a rotary shaker. After this period of time the culture was centrifuged at $8000 \mathrm{rpm}$ for $15 \mathrm{~min}$ at $4{ }^{\circ} \mathrm{C}$ and the cell free supernatant was used as the crude enzyme preparation. Xylanase was assayed by DNS method (Miller 1959) using wheat bran xylan (1\%) as substrate and phosphate buffer at pH 7 and $50^{\circ} \mathrm{C}$. One unit of xylanase is defined as the concentration of enzyme that catalyzes the formation of $1 \mu$ mole of product (xylose) $\mathrm{ml}^{-1} \mathrm{~min}^{-1}$ under the assay conditions. The concentration of enzyme in crude biological preparation is expressed as unit/ml $(\mathrm{U} / \mathrm{ml})$ or unit/litter $(\mathrm{U} / \mathrm{L})$. Cellulase was assayed according to Mandels and Sternburg (1976) using sodium citrate buffer. One unit of cellulase is defined as the amount of the enzyme that liberates $1 \mu \mathrm{mol}$ reducing sugar as glucose $\mathrm{ml}^{-1} \mathrm{~min}^{-1}$ under the assay conditions. The soluble protein content in the crude extract was determined according to Lowry et al (1951) using bovine serum albumin as the standard.

Optimization of cultural parameters: In order to get xylanase, the bacterium was grown in the liquid cultural medium. Various physical and nutritional parameters for xylanase production were optimized by maintaining all factors at a constant level except the one being studied. The parameters studied in our laboratory were $\mathrm{pH}$, temperature, carbon and nitrogen sources, $\%$ of xylan, incubation period and metal salts. The effect of $\mathrm{pH}$ on xylanase production was assessed by cultivating the strain Bacillus $\mathrm{sp}$. in media of varied $\mathrm{pH}$ ranging from 5.0-11.0. The influence of temperature on xylanase production was studied by cultivating the strain Bacillus sp. at different temperatures such as $30^{\circ} \mathrm{C}, 40^{\circ} \mathrm{C}, 50^{\circ} \mathrm{C}, 60^{\circ} \mathrm{C}$ and $65^{\circ} \mathrm{C}$. Xylanase production by Bacillus sp. was studied by cultivating the strain in a set of media having different carbon sources such as wheat bran xylan, birch wood xylan, oat spelt xylan, rice bran xylan, glucose, xylose, lactose, cellobiose, cellulose, carboxymethyl cellulose and starch. Xylanase production from Bacillus sp. was also examined in a set of media containing wheat bran xylan with various percentages $(0.5 \%, 1.0 \%, 2.0 \%, 3.0 \%$ and $4.0 \%)$.

To select the best nitrogen sources for xylanase production by Bacillus sp., both organic and inorganic nitrogen sources were incorporated separately into the production media. Different nitrogen sources used in 
media were peptone, yeast extract, tryptone, casein, urea, asparagine, ammonium phosphate and potassium nitrate. Incubation period is also one important factor for the production of enzyme in highest amount. In this case the strain Bacillus sp. was cultivated with various incubation periods such as $24 \mathrm{~h}, 36 \mathrm{~h}, 48 \mathrm{~h}, 60 \mathrm{~h}, 72$ $\mathrm{h}$ and $96 \mathrm{~h}$. A variety of metal salts that have different effect on the production of enzyme from microorganism due to their stimulatory and inhibitory effect on xylanase production was assessed by cultivating the strain in media keeping all other constituents constant except salt.

Effect of $\mathrm{pH}$ and temperature on xylanase activity: The xylanase partially purified from Bacillus sp by ammonium sulfate saturation and heat treatment was assessed for its activity in different $\mathrm{pH}$ and temperature. The effect of $\mathrm{pH}$ on xylanase activity over wheat bran xylan was studied in $50 \mathrm{mM}$ phosphate buffer with various desired $\mathrm{pH}$ ranging from 5.0-11.0. The effect of temperature on xylanase activity was examined by incubating the reaction mixtures at the desired temperatures ranging from $30-80^{\circ} \mathrm{C}$.

Substrate specificity of xylanase: To determine the substrate specificity of xylanase towards various substrates including wheat bran xylan, rice bran xylan, oat spelt xylan, birch wood xylan, cellulose, carboxymethyl cellulose and starch were used as substrate. The activity of xylanase towards substrates was determined by DNS method..

\section{Results}

The strain Bacillus sp. isolated from soil was identified according to the Bergey's Manual of Systematic Bacteriology. The isolate was an aerobic, endospore forming, gram positive, rod-shaped bacterium producing a clear zone on xylan agar plate.

In our laboratory, the influence of various cultural factors on the production of xylanase was studied. The production of xylanase from Bacillus sp. was better in alkaline pH (Fig. 1a) but the highest (3800 U/L) being observed at pH 8.0 and declined sharply at pH values on either side of this optimum $\mathrm{pH}$. The production of xylanase by Bacillus $\mathrm{sp}$ was excellent at a temperature rang from $30-65^{\circ} \mathrm{C}$, but the optimum temperature for the production of xylanase $(3800 \mathrm{U} / \mathrm{L})$ was found to be $50-55^{\circ} \mathrm{C}$ (Fig. 1b). The carbon sources in the media exerted a profound effect on the enzyme production behavior of the bacterium. Some carbon sources supported good growth with low enzyme production, while others supported good growth as well as enzyme secretion. In the case of Bacillus sp., wheat bran xylan (1\%) supported a high enzyme secretion (Fig. 2), followed by oat spelt xylan, rice bran xylan and birch wood xylan; but mono- and di- saccharides failed to support high xylanase titres. The production of xylanase at different percentage of wheat bran xylan was assessed and it was observed that the medium containing $0.5 \%$ of wheat bran xylan was suitable for maximum xylanase production ( $4000 \mathrm{U} / \mathrm{L}$ ) by Bacillus sp. (Fig. 3). The best nitrogen source for xylanase production by Bacillus sp. was peptone, followed by tryptone and yeast extract, conversely xylanase production was not supported by ammonium nitrate, potassium nitrate, asparagine and casein (Fig. 4). The production of xylanase was found to be (3400 U/L) when peptone was used as nitrogen source but in case of tryptone and yeast extract the enzyme activity were (3100 U/L) and $(2800 \mathrm{U} / \mathrm{L})$ respectively. The time course of xylanase production from Bacillus sp. was investigated and maximum production (4000 U/L) was observed between 48-60 hours (Fig. 5). Further incubation after this period did not show any increment in the level of enzyme production. Metal salts had a profound effect on the production of xylanase. Among the different metal salts $(2 \mathrm{mM})$ tested, $\mathrm{Ca}^{2+}$ and $\mathrm{Mg}^{2+}$ enhanced xylanase production from Bacillus sp. but $\mathrm{Cu}^{2+}, \mathrm{Cd}^{2+}$ and $\mathrm{Hg}^{2+}$ strongly inhibited xylanase production (Fig. 6).

The effect of $\mathrm{pH}$ on xylanase activity was assessed at various $\mathrm{pH}$ values ranging from 5.0-11. The xylanase of the Bacillus sp. exhibited good activity around the $\mathrm{pH}$ range 7-10, but the optimum $\mathrm{pH}$ of the xylanase activity was 9.0 (Fig. 7a). The effect of temperature on the activity of xylanase obtained from Bacillus sp. was examined in the temperature range of $30-80^{\circ} \mathrm{C}$. The xylanase showed best activity around $50-60^{\circ} \mathrm{C}$ with 

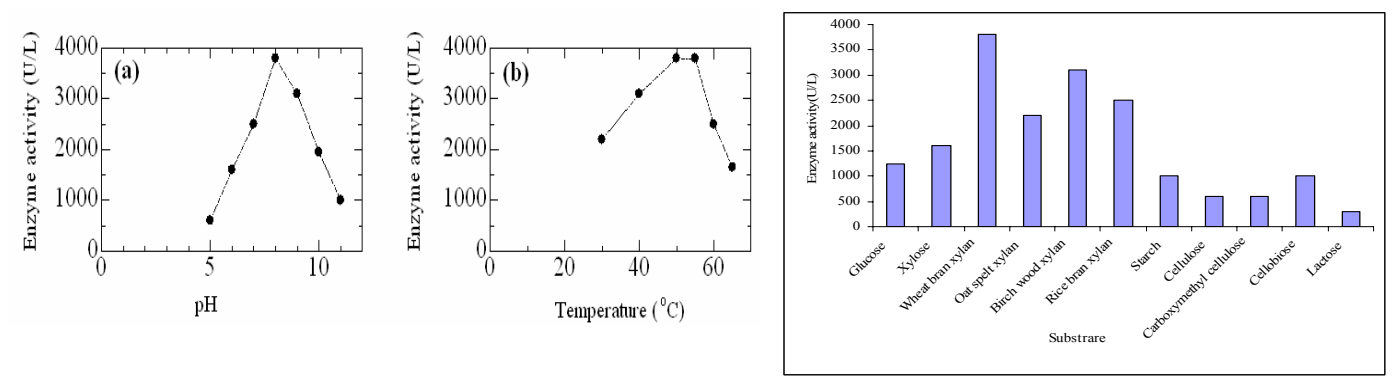

Fig. 1. Effect of $\mathrm{pH}$ (a) and temperature (b) on xylanase production by Bacillus sp.

Fig. 2. Effect of different carbon sources on xylanase production by Bacillus sp.

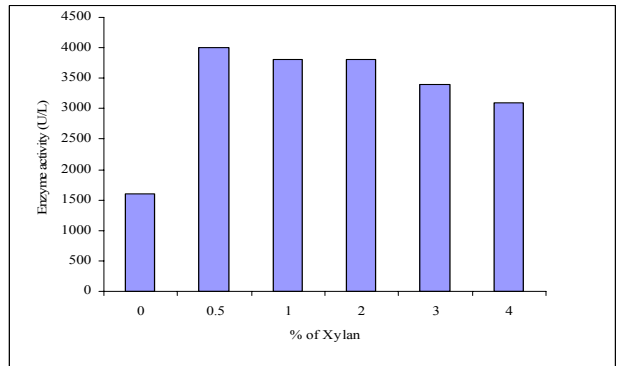

Fig. 3. Effect of $\%$ of xylan on xylanase production by Bacillus $\mathrm{sp}$.

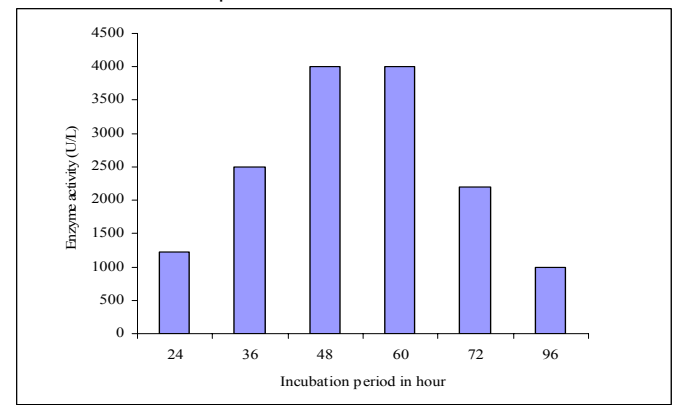

Fig. 5. Effect of incubation period on xylanase production by Bacillus $\mathrm{sp}$.
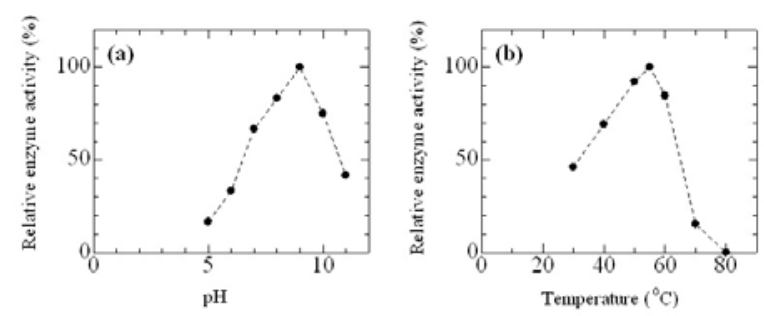

Fig. 7. Effect of $\mathrm{pH}$ (a) and temperature (b) on xylanase activity

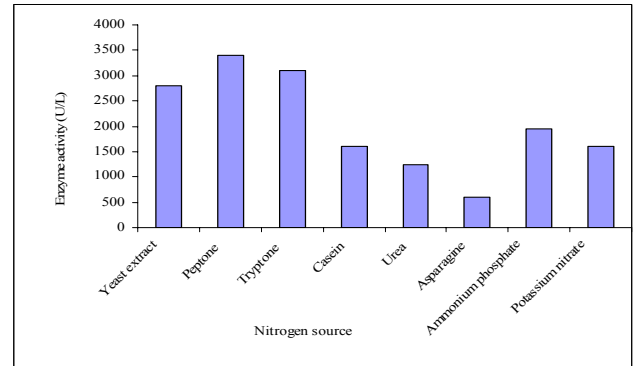

Fig. 4. Effect of various nitrogen sources on xylanase production by Bacillus $\mathrm{sp}$.

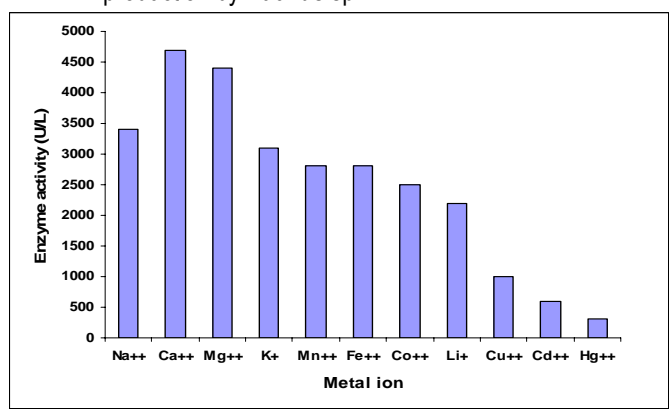

Fig. 6. Effect of different metal ions on xylanase production by Bacillus sp.

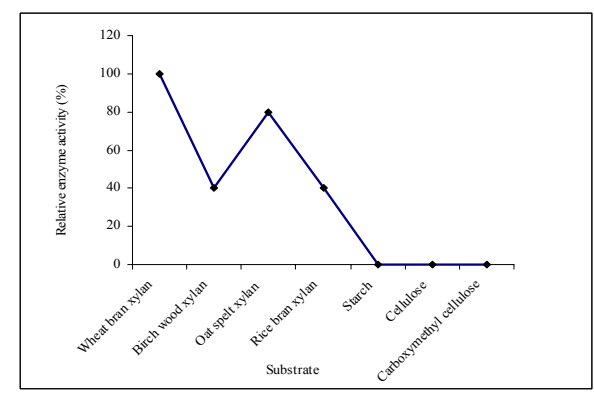

Fig. 8. Substrate specificity of xylanase 
optimum activity at $55^{\circ} \mathrm{C}$ (Fig. $7 \mathrm{~b}$ ). With further rise of the temperature above optimum value, the activity of xylanase gradually decreased and $15 \%$ of the activity was only retained at $70^{\circ} \mathrm{C}$ but destroyed at $80^{\circ} \mathrm{C}$. The substrate specificity of xylanase was studied using various polysaccharides as the substrates. The xylanase of Bacillus sp. was able to strongly hydrolyze wheat bran xylan, oat spelt xylan, rice bran xylan and birch wood xylan, but the xylanase showed highest substrate activity towards wheat bran xylan (Fig. 8) and no activity towards cellulose, carboxymethyl cellulose and starch, and it was a true xylanase.

\section{Discussion}

Xylanases are widely used enzymes in paper and pulp industries as well as in food, animal feed and pharmaceutical industries. Members of the genus Bacillus produce a great variety of extracellular enzymes, of which xylanases are of significant industrial importance. In general cellulase free xylanases produced by thermophilic microorganisms are usually more thermostable than their mesophilic counterparts (Techapun et al. 2003) and the cellulase free xylanases have also been reported from other microbial strains, such as $B$. amyloliquefaciens (Breccia et al.1998) and B. licheniformis A99 (Arehana and Satyanarayana 1998), but most are not alkali stable. The xylanase of Bacillus sp. studied in our laboratory was cellulase free and active at elevated temperatures and in an alkaline $\mathrm{pH}$ environment.

The cultural conditions were found to have profound influence on xylanase production. The initial $\mathrm{pH}$ of the medium has been reported to strongly influence many enzymatic systems by affecting the transport of a number of chemical products and enzymes across the cell membrane (Moon and Parulekar 1991). In the present study, the optimum $\mathrm{pH}$ for the production of xylanase of Bacillus $\mathrm{sp}$. was 8.0. However, the optima for xylanases production from many bacteria was reported in the neutral $\mathrm{pH}$ range such as $B$. circulans WL12 (Esteban et al. 1982) and B. thermoleovorans strain K-3d (Sunna et al.1997). The maximum production of xylanase by Bacillus sp was between $50^{\circ}-55^{\circ} \mathrm{C}$ that is similar to the optimum temperature $\left(55^{\circ} \mathrm{C}\right)$ recorded for the release of xylanase from Neocallimastix frontalis (Mountfort et al.1989).

In our laboratory, it was seen that wheat bran xylan supported a high xylanase production from Bacillus sp than other substrate. The cost effective hemicellulosic substrates such as corncobs, wheat straw, rice bran, rice straw, corn stalks and sugar cane bagasse have been found to support xylanase production (Kulkarni et al. 1999). A similar finding also reported for Streptomyces sp. (Vyas et al. 1990), Trichoderma reesei (Bailey et al. 1993) and Melano carpus albomyces II-68 (Saraswat and Bisaria 1997). It was found that the xylanase production by Bacillus sp became maximum when the medium containing $0.5 \%$ wheat bran xylan. The induction of xylanase by xylan has been reported in various xylanase-producing microorganisms like Trametes trogii (Levin and Forschiassin 1998), Streptomyces sp. QG-II-3 (Beg et al. 2000) and Humicola lanuginose (Kamra and Satynarayana 2004). The effect of different nitrogen sources on xylanase production was also examined and it was found that the maximum xylanase production was attained when peptone is used as nitrogen source. A high xylanase titre was obtained from B. circulans AB16 (Dhillon et al. 2000), when tryptone was used as a nitrogen source, while high xylanase production was observed in yeast extract (Bakri et al. 2003, Purkarthofer et al.1993). Incubation period is a significant parameter in xylanase production. The time course for highest xylanase production was 48-60 h. This finding was in accordance with the work reported by Irwin and Wilron (1993). Xylanase production was increased in the presence of $\mathrm{Ca}^{2+}$ and $\mathrm{Mg}^{2+}$ in the medium, while decreased by $\mathrm{Cd}^{2+}$ and $\mathrm{Hg}^{2+}$ due to their positive and negative modulating ability on xylanase secretion.

In the present study, the optimum pH for xylanase of Bacillus sp. was 9.0. However the $\mathrm{pH}$ optima for xylanases isolated from many bacteria was reported in the neutral $\mathrm{pH}$ range, for example, xylanase of Dictyoglomus thermolacticum exhibited optimum activity at pH 7 (Mathrani and Ahring 1992). Xylanase from Bacillus sp. was thermostable. The enzyme was stable up to $70^{\circ} \mathrm{C}$, but thermally inactivated at $80^{\circ} \mathrm{C}$. The 
enzyme showed optimum activity at $55^{\circ} \mathrm{C}$. Xylanase of Streptomyces livindas 1326 was optimally active at $60^{\circ} \mathrm{C}$ and $\mathrm{pH} 6$ (Morosoli et al. 1986). Xylanase that are active at high temperature and $\mathrm{pH}$ values are required in the pulp and paper industry (Karlsson et al. 1998). Xylanase of Bacillus sp. showed the highest substrate activity towards wheat bran xylan, but no activity towards cellulose, carboxymethyl cellulose and starch. Thus it was a true cellulase free xylanase. Xylanase produced by Aeromonas caviae ME-1 did not hydrolyze starch, cellulose and carboxymethyl cellulose (Kubata et al.1995) and xylanase from Streptomyces lividans-1326 showed no activity towards carboxymethylcellulose (Morosoli et al. 1986). The cellulase free xylanase will be more applicable and beneficial in pre-bleaching of paper pulp because cellulase may adversely affect the quality of the paper pulp by destroying the structure of cellulose.

\section{Conclusions}

From the study it can be concluded that the production of xylanase by Bacillus sp. was markedly increased through optimization of process parameters. This observation is interesting due to the low cost of carbon source since wheat bran xylan is a less expensive substrate for xylanase production in commercial scale than oat spelt xylan. The maximum production of xylanase was achieved after $48 \mathrm{~h}$ of inoculation at pH 8.0 and $50-55^{\circ} \mathrm{C}$. The xylanase of Bacillus sp. was optimally active at $\mathrm{pH} 9.0$ and $55^{\circ} \mathrm{C}$ as well as showed high substrate activity to wheat bran xylan, but no activity towards cellulose, carboxymethyl cellulose and starch. Thus the xylanase of Bacillus sp. was alkali-thermostable and cellulase free, that will be significantly useful in pre-bleaching pulp in the paper industry and improving nutritive value of animal feed.

\section{References}

Arehana A, Satyanarayana T. 1998. Cellulase-free xylanase production by thermophilic Bacillus licheniformis A99. Indian J Microbio/ 38, 135-139.

Bailey MJ, Buchert J, Viikari L. 1993. Effect of pH on production of xylanase by Trichoderma reesei on xylan and cellulose-based media. Appl Microbiol Biotechnol 40, 224-229. http://dx.doi.org/10.1007/BF00170371

Bakri Y, Jacques P, Thonart P. 2003. Xylanase production by Penicillium canescens 10-10c in solid-state fermentation. Appl Biochem Biotechnol 108, 737-748. http://dx.doi.org/10.1385/ABAB:108:1-3:737

Beg QK, Bhushan B, Kappor M, Hoondal G. 2000. Production and characterization of thermostable xylanase and pectinase from Streptomyces sp. QG-11-3. J Indust Microbiol Biotechnol 24, 396-402. http://dx.doi.org/10.1038/sj.jim.7000010

Bocchini DA, Damiano V, Gomes E, Da Silva R. 2003. Effect of Bacillus circulans DI themostable xylanase on bio-bleaching of Eucalyptus Kraft Pulp. Appl Biochem Biotechnol 106, 393-402. http://dx.doi.org/10.1385/ABAB:106:1-3:393

Breccia JD, Sifieriz F, Baigori MD, Castro GR, Hatti-Kaul R. 1998. Purification and characterization of a thermostable xylanase from Bacillus amyloliquefaciens. Enzyme Microbiol Technol 22, 42-49. http://dx.doi.org/10.1016/S0141-0229(97)00102-6

Dhillon A, Gupta JK, Khanna S. 2000. Enhanced production, purification and characterization of a novel cellulase-poor, thermostable alkalitolerant xylanase from Bacillus circulans AB16. Process Biochem 35, 210-215. http://dx.doi.org/10.1016/S00329592(99)00152-1

Esteban R, Villanueva JR, Villa TG. 1982. $\beta$-D-xylanases of Bacillus circulans WL-12. Can J Microbiol 28, 733-739. http://dx.doi.org/10.1139/m82-112

Gubitz GM, Haltrich D, Latal B, Steiner W. 1997. Mode of depolymerization of hemicellulose by various mannanases and xylanases in relation to their ability to bleach softwood pulp. Appl Microbiol Biotechnol 47, 658-662. http://dx.doi.org/10.1007/s002530050991

Haltrich D, Nidetzky B, Kulbe KD, Steiner W, Zupancic S. 1996. Production of fungal xylanases. Bioresour Technol 58, 137-161. http://dx.doi.org/10.1016/S0960-8524(96)00094-6

Holt JG, Krieg NR, Sneath PHA, Staley JT, Williiams ST. 1993. Bergey's Manual of Determinative Bacteriology. 9th edn. Williams and Wilkins,Baltimore.

Irwin D, Wilron DB. 1993. Characterization and sequence of a hermomonospora fusta xylanase. Appl Environ Microbiol 60, 763-770. 
Kamra P, Satynarayana T. 2004. Xylanase production by the thermophilic mold Humicola lanuginosa in solid-state fermentation. Appl Biochem Biotechnol 119, 145-157. http://dx.doi.org/10.1385/ABAB:119:2:145

Karlsson EN, Dahlberg L, Jorto N, Gorton L, Holst H. 1998. Enzymatic specificity and hydrolysis pattern of the catalytic domain of the xylanase (Xyn) from Rhodothermus marinus. J Biotechnol 60, 20-35.

Krengel U, Dijkstra BW, Bioson AF. 1996. Three-dimensional structure of endo-1, 4-beta-xylanase 1 from Aspergillus niger. Molecular basis for its low pH optimum. J Mol Biol 263, 70-78. http://dx.doi.org/10.1006/jmbi.1996.0556. PMid:8890913

. Kubata BK, Takamizawa K, Kawai K, Suzuki T, Horitsu H. 1995. Xylanase IV, an exoxylanase of Aeromonas caviae ME-1 which produces xylotetraose as the only low molecular weight oligosaccharide from xylan. Appl Environ Microbiol 61(4), 1666-1668. PMid:16535010, PMCid:1388428

Kulkarni N, Shendye A, Rao M. 1999. Molecular and biological aspects of xylanases. FEMS Microbiol Rev 23, 411-456. http://dx.doi.org/10.1111/j.1574-6976.1999.tb00407.x. PMid:10422261

Levin L, Forschiassin F. 1998. Influence of growth conditions on the production of xylanolytic enzymes by Tranetes trogii. World $\mathrm{J}$ Microbiol Biotechnol 14, 443-446. http://dx.doi.org/10.1023/A:1008885800035

Lowry OH, Rosebrough NJ, Farr AL, Randall RJ. 1951. Protein measurement with the Folin-phenol reagent. J Biol Chem 193, 265-275. PMid: 14907713

Mandels M, Sternburg D. 1976. Recent advances in cellular technology. J Ferment Technol 54, 267-286.

Mathrani IM, Ahring BK. 1992. Thermophilic and alkaliphilicxylanase from several Dictyoglo mus isolates. Appl Microbiol Biotechnol 38, 23-27. http://dx.doi.org/10.1007/BF00169413

Miller GL. 1959. Use of dinitrosalicylic acid reagent for determination of reducing sugars. Anal Chem 31, 426-428. http://dx.doi.org/10.1021/ac60147a030

Moers K, Courtin CM, Brijs K, Delcour JA. 2003. A screening method for endo-beta-1, 4-xylanase substrate selectivity. Anal Biochem 319, 73-77. http://dx.doi.org/10.1016/S0003-2697(03)00161-1

Moon SH, Parulekar SJ. 1991. A parametric study of protease production in batch and fed batch cultures of Bacillus firmus. Biotechnol Bioeng 37, 467-483. http://dx.doi.org/10.1002/bit.260370509. PMid:18597393

Morosoli R, Bertrand JL, Mondou F, Shareck F. 1986. Purification and properties of a xylanase from Streptomyces lividans. JBiochem $239,587-592$.

Mountfort, Douglas O, Rodney A, Asher. 1989. Production of xylanase by the ruminal anaerobic fungus Neocallimastix frontalis. Appl Environ Microbiol. 55, 1016-1022. PMid:2729975, PMCid:184239

Nunez LZ, Rodriguez R, Baez MA. 2001. Gas retention mechanism in wheat bread doughs. The role of xylanase and arabinoxylain fractions. J Biochem 56, 31-33.

Prema P. 2005. Xylanases. In: Pandey A. Webb C, Soccol CR, Larroche C, ed. Enzyme technology. New Delhi, Asiatech Publ, 333-346.

Purkarthofer H, Sinner M, Steiner W.1993. Cellulase-free xylanase from Thermomyces lanuginosus: Optimization of production in submerged and solid-state culture. Enzyme Microbiol Technol 15, 677-682. http://dx.doi.org/10.1016/0141-0229(93)90068-D

Saha BC. 2003. Hemicellulose bioconversion. J Indian Microbiotechnol 30, 279-291.

Saraswat V, Bisaria VS. 1997. Biosynthesis of xylanolytic and xylan-debranching enzymes in Melanocarpus albomyces 11S 68. J Ferment Bioeng 83, 352-357. http://dx.doi.org/10.1016/S0922-338X(97)80141-9

Senior DJ, Hamilton J, Bernier RL, Manoir JR. 1992. Reduction in chlorine use during bleaching of kraft pulp following xylanase treatment. Wood Pulp Chem 27, 125-130.

Sudha B, Veeramani H, Sumathi S. 2003. Bleaching of bagasse pulp with enzyme pre-treatment. Water Sci Technol 47, 163-168.

Sunna A, Prowe SG, Stoffregen T, Antranikian G. 1997. Characterization of the xylanases from the newly isolated thermophilic xylan degrading Bacillus thermoleovorans strain K-3d and Bacillus flavothermus strain LB3A. FEMS Microbiol Lett 148, 209-216. http://dx.doi.org/10.1111/j.1574-6968.1997.tb10290.x

Techapun C, Poosaran N, Watanabe M, Sasaki K. 2003. Thermostable and alkaline-tolerant microbial cellulase-free xylanases produced from agricultural wastes and the properties required for use in pulp bleaching bioprocesses a review. Process Biochem 38, 1327-1340. http://dx.doi.org/10.1016/S0032-9592(02)00331-X

Tolan JS, Canovas RV. 1992. The use of enzymes to decrease the $\mathrm{Cl}_{2}$ requirements in pulp bleaching. Pul Pap Can 93, 39-42. 
Tucker MP, Mohagheghi A, Grohmann K, Himmel ME. 1989. Ultra-thermostable cellulases from Acidothermus cellulolyticus: Comparison of temperature optima with previously reported cellulases. Biotechnology 7, 817-820. http://dx.doi.org/10.1038/nbt0889-817

Tuohy MG, Buckley RJ, Griffin TO, Connelly IC, Shanley NA, Filho EXF. 1989. Enzyme production by solid-state cultures of aerobic fungi on lignocellulosic substrates. In: Coughlan MP, ed. Enzyme systems for lignocellulose degradation. London, Elsevier, 293-312.

Viikkari L, Ranua M, Kantelinen A, Sunduist J, Linko M. 1986. Bleaching with enzymes. In: Proc 3rd Int Conf. Biotechnology in the Pulp and Paper Industry. STFI, Stockholm, Sweden,67-69.

Vyas P, Chauthaiwale V, Phadatare S, Deshpande V, Srinivasan MC. 1990. Studies on the alkaliphilic Streptomyces with extracellular xylanolytic activity. Biotechnol Lett 12, 225-228. http://dx.doi.org/10.1007/BF01026804

Xu Z, Bai Y, Sun W, Tao W. 2000. Screening and fermentation conditions of a bacterial strain over-producing xylanase. Wei Sheng Wu Xue Bao 40(4), 440-443. PMid:12548969

Yin YL, Baidoo SK, Jin LZ, Liu, YG, Schulze H, Simmins PH. 2001. The effect of different carbohydrate and protease supplementation on apparent (ideal and overall) digestibility of nutrients of five hulless barley varieties in young pigs. Livest Prod Sci 71, 109120. http://dx.doi.org/10.1016/S0301-6226(01)00215-9 